\title{
Structural Prediction Model Satisfaction and Buying Decision of Muslim Consumers Towards Fast Food by Halal Labeling
}

\author{
Intan Nurrachmi ${ }^{a}$, Setiawan ${ }^{b}$, I GustiBagus Rai Utama ${ }^{c}$ \\ ${ }^{a}$ Universitas Islam Bandung, Indonesia \\ ${ }^{\mathrm{b}}$ PoliteknikNegeri Bandung, Indonesia \\ ${ }^{c}$ DhyanaPura University, Bali, Indonesia \\ Corresponding email: raiutama@undhirabali.ac.id
}

\begin{abstract}
This exploration means to comprehend what impacts Muslims in Bandung in creation choices on purchasing inexpensive food. The objects of this exploration are Muslim cheap food customers in Bandung. Information was gathered through an overview utilizing polls as a helping instrument. There were 180 respondents as tests. The information examination was led utilizing Structural Equation Modeling - Partial Least Square (SEM-PLS) approach. The exploration results show that the halal logo has a positive and critical impact on purchasing choices and that the clients' fulfillment likewise has a positive and huge effect on purchasing choices. Moreover, buyers' fulfillment can intervene in the impact of the halal logo on purchasing choices. This examination result is relied upon to urge eatery supervisors to be more mindful of the significance of the halal logo on their items.
\end{abstract}

Keywords:halal logo, brand trust, satisfaction, buying decision, fast food

\section{Introduction}

Brand trust has an important role in the buying decisions of a product. The brand trust could only be achieved if the marketer could create and keep a positive emotional connection with their consumers. Such a connection could not be built in a short period of timeit has to be done consistently and constantly so it will produce trust. This trust will affect the buying decisions of a product. Therefore, to drive a buying decision, the marketer should create consumers' trust in a brand. The brand trust could be interpreted as consumers' desire to lean on a brand with risks to face because thetrust in the brand will cause a positive result (Soon, et al., 2017; Amron, 2018).

Consumers are faced with all kinds of products for their daily needs. One of the products they need every day is food. There are many restaurants that provide food supplies, from snacks to main dishes. Some consumers, particularly millennials, tend to choose fast food over buying groceries to make their own food at home. Consumers' interest in the fast-food is increasing over the year, with the result that fast-food chains and restaurants are soaring in numbers. Some of the restaurants in Indonesia are KFC, Pizza Hut, A\&W, California Fried, Hoka-Hoka Bento, McDonald's, and et cetera. One of the factors that because consumers decide to buy food from those restaurantsis the trust they have in the brand (Dwik\&Samboro,2019). When they buy the products, it means they have been satisfied with them. Consumers would agree on much to anything the brand gives and provides to them. But, on the other side, it has been found that many consumers do not trust the halal food providers enough to engage in a food exchange relationship with them. Some researchpreviously found that brand trust affects significantly halal food consumption, moreover, it also has a big influence on consumers' attitude and subsequent behavior (Ali, et al., 2017; Setiawan, \&Mauluddi, 2019).

There are a couple of other factors that cause consumers to decide to buy fast food products. Some research stated that the halal logo has a positive and significant influence on buying decisions of fast food products (Ferrinadewi, 2008). This is because most of the Indonesian citizens are Muslims, so when they choose some products they would refer to the teachings of Islam, which is the products, which should be clearly permissible or lawful Islamic ally. Muslim consumers would find products with halal labels on them to make sure that the food they consume is not contradicted with the Islamic teachings (Hanaysha, 2018). Sumarwanstated that the knowledge of halalfood is an important thing for the citizens of Indonesia particularly Muslims (Sumarwan, 2014; Nurul, 2016). Muslim consumers tend to choose products that are stated as halal by the authority, so the existence of a halal label will have an influence on the consumer behavior of choosing a product (Sumarwan, 2014; Simanjuntak, \&Murti, 2019; Setiawan, et al., 2020).

Those factors are interesting to be studied because it is important to know what makes Indonesian Muslim consumers choose a product and decide to buy it. This research aims to understand how much product quality, halal logo, and brand trust affect the fast food buying decision in Bandung (Sumarwan, 2014; Amron, 2018; Ali, et al., 2017; Hanaysha, 2018; Simanjuntak, \&Murti, 2019).

\section{Research Methodology}

This research is a survey research using a questionnaire as an assisting instrument to gain primary data. The questionnaire was aimed at respondents who are Muslims in Bandung. Random sampling was conducted. 
Instruments were measured using the Likert 5 points scale, from 1 (strongly disagree) to 5 (strongly agree), used to measure all scale items (Utama, 2016). The questionnaire was divided into 3 main parts, from a brief explanation about the objects of the survey, followed by the measurement of the main scale item. The third part was used to measure the participants' demographic profiles, genders, ages, and levels of education. Data analysis wasconducted using Structural Equation Modeling - Partial Least Square (SEM-PLS)approaches (Afthanorhan, 2013).

\section{Results and Discussion}

\subsection{Respondents' Demography}

Data were collected from 180 Muslim respondentsin Bandung. Before data analysis, respondents' demography is presented firstin table 2 to see the characteristics of the participants used as research samples.

Table 2. Respondents' Demography

\begin{tabular}{llrr}
\hline Criteria & Description & Frequency & Percentage \\
\hline Gender & Male & 38 & 21.11 \\
& Female & 142 & 78.89 \\
\hline \multirow{2}{*}{ Age } & $<$ 20 years of age & 24 & 13.33 \\
& $20-39$ years of age & 146 & 81.11 \\
& $\geq 40$ years of age & 10 & 5.56 \\
\hline \multirow{2}{*}{ Levels of Education } & S High School diploma & 111 & 61.67 \\
& Bachelor's Degree & 69 & 38.33 \\
& Master's Degree & 0 & 0.00 \\
\hline
\end{tabular}

Based on the table above, there are more female respondents than male ones with a percentage of 78.89 percent females and 21.11 percent males. Respondents that are under 20 years old are 13.33 percent, the biggest age group is those who are 20 to 39 years old with a percentage of 81.11 percent, and the remaining are those who are 40 years old or more as many as 5.56 percent. Meanwhile, the respondents' levels of education are dominated by those who have high school diplomas as many as 61.67 percent, followed by those with a bachelor's degree at 38.33 percent.

\subsection{Validity and Reliability Test}

There are 4 variables in this research that are adapted from the previous research, which are halal logo, brand trust, satisfaction, and buying decision. In this research, the validity test that wasdone is the convergent validity test. With the cut-off value for Factor Loading $>0.50$ composite reliability $(\mathrm{CR})>0.70$ and average variants extracted $>0.50$

Tabel 3. Validity and Reliability Test

\begin{tabular}{|c|c|c|c|c|}
\hline Variables & Loading & Cronbach $\alpha$ & $\mathrm{CR}$ & AVE \\
\hline Halal Logo & & 0.742 & 0.854 & 0.814 \\
\hline $\begin{array}{l}\text { Halal logo is important in choosing a } \\
\text { product }\end{array}$ & 0.849 & & & \\
\hline $\begin{array}{l}\text { I will choose a product based on the } \\
\text { halal logo as a priority }\end{array}$ & 0.871 & & & \\
\hline $\begin{array}{l}\text { I will always be careful when } \\
\text { choosing a product with a halal logo }\end{array}$ & 0.715 & & & \\
\hline Brand Trust & & 0.879 & 0.912 & 0.822 \\
\hline $\begin{array}{l}\text { The provider/marketer of the halal } \\
\text { product can be trusted }\end{array}$ & 0.798 & & & \\
\hline $\begin{array}{l}\text { Provider or marketer of the halal } \\
\text { product do not make fake claims on } \\
\text { their products }\end{array}$ & 0.781 & & & \\
\hline $\begin{array}{l}\text { I believe the information given by } \\
\text { the provider/marketer to the } \\
\text { consumers is accurate }\end{array}$ & 0.909 & & & \\
\hline $\begin{array}{l}\text { I believe that the halal label of the } \\
\text { product is accurate }\end{array}$ & 0.848 & & & \\
\hline $\begin{array}{l}\text { I believe that the halal logo on the } \\
\text { product is reliable }\end{array}$ & 0.768 & & & \\
\hline Satisfaction & & 0.886 & 0.930 & 0.903 \\
\hline
\end{tabular}




\begin{tabular}{lrrrrr}
\hline Variables & Loading & Cronbach $\alpha$ & CR & AVE \\
\hline $\begin{array}{l}\text { I am happy consuming halal food } \\
\text { I think consuming halal food is a } \\
\text { good idea }\end{array}$ & 0.920 & & & & \\
$\begin{array}{l}\text { I am content with the whole } \\
\text { experience of being a halal food } \\
\text { consumer }\end{array}$ & 0.938 & & & & \\
\hline Buying Decision & 0.848 & & & & \\
\hline $\begin{array}{l}\text { I feel comfortable with my decision } \\
\text { to buy a product of this shop's brand }\end{array}$ & 0.773 & & & & \\
$\quad \begin{array}{l}\text { I will recommend this shop's brand } \\
\text { positively to other people }\end{array}$ & 0.620 & & & \\
$\quad \begin{array}{l}\text { I often buy from this shop's brand } \\
\text { I intend to buy again from this } \\
\text { shop's brand in the future }\end{array}$ & 0.716 & & & \\
$\quad \begin{array}{l}\text { Overall, I am satisfied with the } \\
\text { product purchasing from this shop }\end{array}$ & 0.817 & & & \\
\end{tabular}

The results of convergent validity test indicate that extracted indicators have good convergent validityvalue (factor loading $=0.532-0.938 ; \mathrm{C} \alpha=0.731-0.836>0.70 \mathrm{CR}=0.824-0.930>0.70 ; \mathrm{AVE}=$ $0.699-0.903>0.50$; seeTable 2).As the conclusion of test result above, it can be said that the extracted indicators have the ability to measure the construction.

\subsection{Hypothesis Test}

To measure average geometric from the equation, Goodness of Fit (GoF) is checked.Other than that, the $\mathrm{R}^{2}$ valuealso needs to be checked to rate how well the model in this research is to be a predictor (results can be seen in the following table 4).

Table 4. Hypothesis Test Result and Goodness of Fit of Model Satisfaction and Buying Decision of Muslim Consumers Towards Fast Food by Halal Labeling

\begin{tabular}{|c|c|c|c|}
\hline Relations & Estimation & P Values & Decision \\
\hline Halal Logo $=>$ Satisfaction & 0.568 & $0.000^{*}$ & Accepted \\
\hline Brand Trust $=>$ Satisfaction & 0.183 & $0.006^{*}$ & Accepted \\
\hline Halal Logo $=>$ Buying Decision & 0.405 & $0.000 *$ & Accepted \\
\hline Brand Trust $=>$ Buying Decision & 0.110 & 0.067 & Denied \\
\hline Satisfaction $=>$ Buying Decision & 0.315 & $0.000 *$ & Accepted \\
\hline Halal $\operatorname{Logo}=>$ Satisfaction $=>$ Buying Decision & 0.179 & $0.000 *$ & Accepted \\
\hline Brand Trust $=>$ Satisfaction $=>$ Buying Decision & 0.058 & 0.135 & Denied \\
\hline \multicolumn{4}{|l|}{ Average $R$-squared $(\mathrm{ARS})=0.545, \mathrm{P}<0.001$} \\
\hline \multicolumn{4}{|c|}{ Average adjusted $R$-squared $(\mathrm{AARS})=0.538, \mathrm{P}<0.001$} \\
\hline \multicolumn{4}{|c|}{ Tenenhaus GoF $(\mathrm{GoF})=0.600$, small $>=0.1$, medium $>=0.25$, large $>=0.36$} \\
\hline \multicolumn{4}{|l|}{ *Significanton level 1\% } \\
\hline
\end{tabular}

Based on theGoodness of Fitresults, it can be seen that the fitness level of the model as a whole is feasible as a good predictor. TheAdjusted $R$ Squarelevelof 0.538 reflects that all independent variables can explain the decisions of buying fast food with the trust level of 53.8 percent. While the remaining 35.4 percent can be explained by other variables that are not researched in this research.

It can be seen that the halal logo affects both satisfaction and buying decision with the estimated coefficient of 0.568 , dan 0.405 consecutively, with a significant value of 0.000 . As the significant value is < 0.01 , it indicates that the halal logo affects satisfaction and buying decisions. The existence of the halal logo becomes one of the considerations to the Muslim consumers who want to buy fast food. Moreover, the halal logo makes Muslim consumers feel satisfied in buying the food products. Muslim consumers need to be assured that the products they choose are halal guaranteed through the halal logo on the products in line with Wibowo, et al., (2018). 


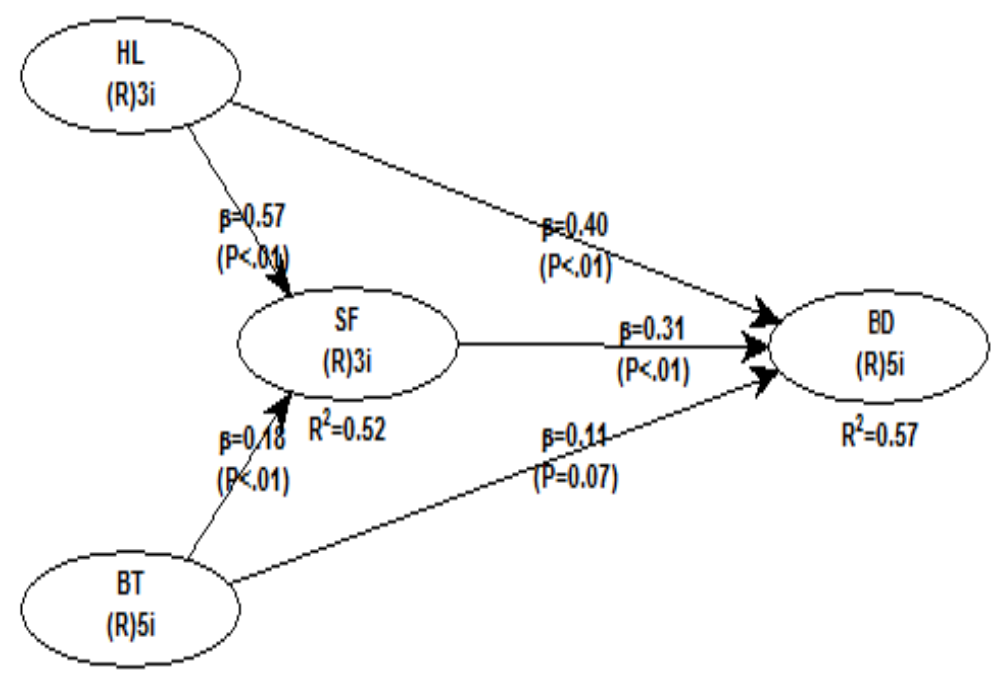

Figure 1. Structural Prediction Model Satisfaction and Buying Decision of Muslim Consumers Towards Fast Food by Halal Labeling

Brand trust's influence on satisfaction and buying decision is 0.183 and 0.110 consecutively, with the probability value of 0.006 , dan 0.067 . Brand trust's significant value to the satisfaction that is $0.000<$ 0.05 indicates that brand trust has an influence on satisfaction, but brand trust's significant value to buying decision is $0.067>0.05$ so the correlation does not affect significantly. This confirmed that Muslim consumers still make brand trust affect the satisfaction of fast food, but this does not necessarily lead to the decision to buy fast food in line with Tjahyadi, (2006).

Furthermore, the effect of satisfaction on buying decisions is 0.315 with a significant value of 0.000 . A significant value of $0,000<0.01$ indicates that satisfaction has an effect on buying decisions. Muslim consumers who are satisfied with a food product can consider repurchasing. Apart from that, the satisfaction variable can mediate the effect of the halal logo and buying decisions with the coefficient of 0.179 and the significant value is $0.000<0.01$.

\section{Conclusions}

The research results indicate that the halal logo affects positively and significantly satisfaction and buying decision, brand trust affects positively and significantly buying decision, satisfaction affects positively and significantly buying decision. Other than that, satisfaction can mediate the effect of the halal logo on buying decisions.

This research result is expected to encourage fast-food restaurant owners and managers to be more aware of the importance of the halal logo on their products. However, it is also expected that they do not neglect to build consumers' trust in their products by providing excellent services and high-quality products.

\section{References}

5. Afthanorhan, W. M. A. B. W. (2013). A comparison of partial least square structural equation modeling (PLS-SEM) and covariance-based structural equation modeling (CB-SEM) for confirmatory factor analysis. International Journal of Engineering Science and Innovative Technology, 2(5), 198-205.

6. Ali, A., Xiaoling, G., Sherwani, M., \& Ali, A. (2017). Factors affecting Halal meat purchase intention. British Food Journal.

7. Amron, A. (2018). The influence of a brand image, brand trust, product quality, and price on the consumer's buying decision of MPV cars. European Scientific Journal, 14(13), 228-240.

8. Dwik, R., \&Samboro, J. (2019). Pengaruh Label Halal Dan HargaTerhadapKeputusanPembelianMakananCepatSajiHokben (Hoka-Hoka Bento). JurnalAplikasiBisnis, 5(1), 17-20.

9. Ferrinadewi, Erna. (2008). Merek Dan PsikologiKonsumen. Yogyakarta: GrahaIlmu

10. Hanaysha, J. R. (2018). Customer retention and the mediating role of perceived value in the retail industry. World Journal of Entrepreneurship, Management, and Sustainable Development.

11. Nurul, R. I. (2016). The Role of Attitude and Subjective Norms in Influencing Students' Purchase Intention to Halal Cosmetics (Doctoral dissertation, UniversitasAndalas).

12. Setiawan, S., and HasbiAssidikiMauluddi. (2019). "Consumer Behaviour on Buying Halal Products in Bandung." At-tijaroh: Management Studies and Islamic Business Journal no. 2 (2019): 232-246. 
13. Setiawan, S., DiharpiHerliSetyowati, and FifiAfiyantiTripuspitorini. (2020). "Risk Dimensions to Consumer in Buying Halal Products." Amwaluna: JurnalEkonomidanKeuanganSyariah 4, no. 1

14. Simanjuntak, M., \&Murti, C. (2019). The Influence of the Consumer's Knowledge of Halal Foods and Purchasing towards Awareness Behavior. Department of Family and Consumer Sciences, Faculty of Human Ecology, IPB University, 181.

15. Soon, Jan Mei, Mahmood Chandia, and Joe Mac Regenstein. (2017). "Halal Integrity in the Food Supply Chain.” British Food Journal 119, no. 1 (2017): 39-51.

16. Sumarwan, Ujang. (2014). PerilakuKonsumen. Teori Dan PenerapannyaDalamPemasaran. Bogor: Ghalia Indonesia

17. Tjahyadi, RullyArlan. (2006). "Brand Trust in Brand Loyalty Context: Brand Characteristic Roles, Company Characteristics, and Brand Customer Relations Characteristics." Management Journal 6, no. 1 (2006): 65-78.

18. Utama, I GustiBagus Rai. (2016). MetodologiPenelitianPariwisatadanHospitalitas. Denpasar: PustakaLarasan.

19. Wibowo, Dwi Edi, and Benny DiahMandusari. (2018). "The Effects of Halal Labelling on Buying Decisions by Muslim Consumers on Food Products in Pekalongan.” Indonesia Jurnal of Halal 1, no. 1 (2018): 73-77. 